\title{
Une nouvelle maladie virale sur Danae racemosa causée par le virus de la mosaïque du chénopode
}

\author{
L Cardin 1*, M Ponchet ${ }^{1}, \mathrm{M}$ Jacquemond 2, B Delecolle ${ }^{2}$ \\ 1 INRA, station de botanique et pathologie végétale, BP 2078, F 06606 Antibes cedex; \\ 2 INRA, station de pathologie végétale, BP 94, F 84143 Montfavet, France
}

(Reçu le 10 avril 1995 ; accepté le 13 juin 1995)

\begin{abstract}
Résumé - Depuis plusieurs années, on observe l'extension importante d'une maladie sur Danae racemosa, liliacée cultivée dans le sud-est de la France pour son feuillage d'ornement. Les symptômes observés sont une marbrure et un jaunissement caractéristiques du feuillage rendant ce dernier impropre à la commercialisation. L'utilisation de techniques virologiques classiques — inoculation d'une gamme d'hôtes, rétro-inoculation systématique, purification, microscopie électronique - ont permis de mettre en évidence la présence régulière d'un virus isométrique (26 $\mathrm{nm})$ à partir des plantes malades de différentes provenances géographiques. À partir de ces premiers résultats, une étude sérologique - immunodiffusion et immunoélectrophorèse en milieu gélosé, technique immunoenzymatique, couplée à une analyse biochimique (détermination des poids moléculaires de la sous-unité capsidiale et de l'acide ribonucléique) — a permis de démontrer qu'il s'agit du virus de la mosaïque du chénopode (Sowbane mosaic virus). L'inoculation du virus sur $D$ racemosa sain a permis de reproduire les symptômes typiques de la maladie et on a réisolé le virus. Le virus de la mosaïque du chénopode est donc le seul agent causal de la marbrure et du jaunissement du feuillage de $D$ racemosa et il est, à notre connaissance, le premier virus signalé sur cette liliacée. Dans la plante malade, le virus est présent à des concentrations très faibles car non détectables par la méthode immunoenzymatique DAS-ELISA et il est nécessaire, pour le mettre en évidence, d'avoir recours à des rétro-inoculations systématiques sur plante hôte sensible (Chenopodium quinoa Wild). La transmission du virus par pucerons a été confirmée (mode non-persistant). Elle doit contribuer, avec la multiplication végétative des plants, à la propagation de la maladie.
\end{abstract}

Danae racemosa / liliacée / virus de la mosaïque du chénopode / marbrure-jaunissement / aphides

Summary - A new virus disease inducing a mottle and a yellowing of ornamental Danae racemosa foliage caused by a Sowbane Mosaic Virus strain. Since the beginning of the 1980s, a disease has been observed on Danae racemosa Moench (Alexander Laurel), a plant of horticultural interest. In the south of France, as in Italy, D racemosa is commonly cultivated for its ornamental foliage, like Asparagus plumosus $L$. This monocot from the Liliaceae family shows typical damage on its foliage: first a mottle appears on the young phylloclades which turn yellow with time. This disease is rarely widespread in a plantation. Only single plant or small areas are usually affected but the regular extension of the disease is responsible for important economic consequences. In the present paper we show that these symptoms are due to the propagation of a virus in the plant. The use of general virological tests, host range inoculation and retroinoculation, purification and EM, demonstrated the systematic presence of isometric virus particles (26 $\mathrm{nm}$ ) in the diseased $\mathrm{D}$ racemosa collected from various geographic areas. The study of the serological properties of the virus (immunodiffusion, immunoelectrophoresis and DAS-ELISA) with the MW determination of the capsid-subunit and the RNA, led to its identification as a Sowbane mosaic virus strain. When healthy D racemosa were inoculated with the virus, the typical symptoms of the disease could only be identified after a long delay ( 9 months after the inoculation) on the young neoformed boughs, from which the virus was isolated. We therefore consider the Sowbane mosaic virus as 
the single pathogen inducing the mottle and the yellowing of the $\mathrm{D}$ racemosa foliage. In the diseased tissues, the virus was present in very low amounts and could not be detected by classical immunoenzymatic assay (DAS-ELISA). Retroinoculation and rare direct inoculations from crude extracts, on a sensitive host (ie Chenopodium quinoa) were necessary to propagate the virus. Disease diagnostic is discussed, especially as the virus seemed to be latent with no external symptoms during a certain growing period of the plant under special conditions (shadowing, high nitrogen fertilization). A rapid and efficient method for detection of the virus is absolutely necessary to carry out a phytosanitary programme and to obtain virus-free plants for vegetative propagation. Evidence was found that the virus could be transmitted by several aphids; this is an important parameter for the control of the disease.

Alexander laurel / Liliaceae / Sowbane mosaic virus / mottle yellowing / aphid transmission

\section{INTRODUCTION}

Le Danae racemosa Moench ou Ruscus racemosus $L$ est une liliacée originaire de Grèce et d'Asie Mineure. Bien acclimatée dans le sud de la France, cette plante horticole utilisée pour son feuillage d'ornement rentre dans la constitution de nombreuses compositions florales. Sa culture, bien que n'occupant que peu de surface (une trentaine d'hectares dans les Alpes-Maritimes), n'en possède pas moins un intérêt économique certain, dans la mesure où la majeure partie de la production est exportée. De plus, compte tenu de la conjoncture actuelle s'orientant vers une diversification des cultures horticoles, la production de feuillage coupé de $D$ racemosa constitue une alternative très intéressante aux productions plus classiques, comme celles de l'Asparagus plumosus $L$, en raison de son aspect très décoratif et de sa longue durée de conservation.

Depuis une dizaine d'années on observe dans les différentes exploitations l'apparition de symptômes importants de marbrure et de jaunissement sur des plantes isolées ou groupées en taches. Le feuillage de $D$ racemosa est constitué de rameaux issus d'une souche rhizomateuse portant des cladodes. Celles-ci extériorisent les symptômes de la maladie : couleur vert-jaune à jaune avec quelques îlots chlorophylliens plus ou moins annulaires, les nervures restant vertes (fig 1). Sur les très jeunes rameaux les symptômes sont plus diffus et d'aspect marbré. La maladie n'affecte pas le port de la plante et aucun flétrissement n'a été signalé. Cette «maladie» en extension régulière depuis son apparition a pour conséquence directe la dépréciation de la qualité du feuillage entraînant son déclassement, voire son rejet au niveau commercial. Ces altérations suggérant une infection de type viral, des techniques classiques de virologie ont été appliquées. La mise en évidence et l'identification du virus responsable de la maladie sont présentées dans cet article.

\section{MATÉRIEL ET MÉTHODES}

\section{Sélection du matériel végétal}

Sur une quarantaine d'échantillons présentant les symptômes décrits précédemment, 8 plantes d'origine géographique diverse (Alpes-Maritimes: Antibes (4), Mandelieu, Pégomas, et Dordogne: Montignac, Brantôme) ont été retenues et placées en serre «insect proof" durant l'étude.

Des plantes saines de $D$ racemosa et de Ruscus hypophyllum provenant du jardin botanique de la Villa Thuret ont été maintenues dans les mêmes conditions. Elles ont fait l'objet de contrôles réguliers (tests biologiques) pour s'assurer de l'absence de virus.

\section{Obtention de l'inoculum primaire et gamme d'hôtes}

Les cladodes de $D$ racemosa sont broyés dans un mortier avec un tampon phosphate de potassium $25 \mathrm{mM}, \mathrm{pH} 7,5-0,5 \%$ 2-mercaptoéthanol (5 ml/gMF). Le broyat est filtré sur étamine et utilisé comme inoculum en présence de charbon actif et de carborundum. Le même protocole est développé lorsqu'il s'agit de feuilles de Chenopodium quinoa Wild - plante de référence - ou de plantes de la gamme d'hôtes. Celle-ci, constituée de 51 espèces appartenant à 18 familles botaniques a été éprouvée avec un isolat de virus provenant de $D$ racemosa malade ( $\mathrm{n}^{\circ} 1$ Antibes) après clonage (lésion locale) sur $C$ quinoa. L'inoculum est constitué par un extrait de feuilles de $C$ quinoa fraîchement récoltées ou conservées à $-18^{\circ} \mathrm{C}$, présentant des symptômes systémiques.

Toutes les espèces sont issues de semis et cultivées dans une enceinte aux conditions climatiques contrôlées, à l'abri des insectes (photopériode de $16 \mathrm{~h}$ de lumière, 10000 lux, $24^{\circ} \mathrm{C}$ ).

Quatre plantes de chaque espèce, au stade 4-6 feuilles bien développées, sont inoculées. La notation des symptômes éventuels se fait régulièrement pendant $15 \mathrm{j}$. Une rétro-inoculation sur $C$ quinoa est effectuée à partir des feuilles inoculées et non-inoculées néoformées. 


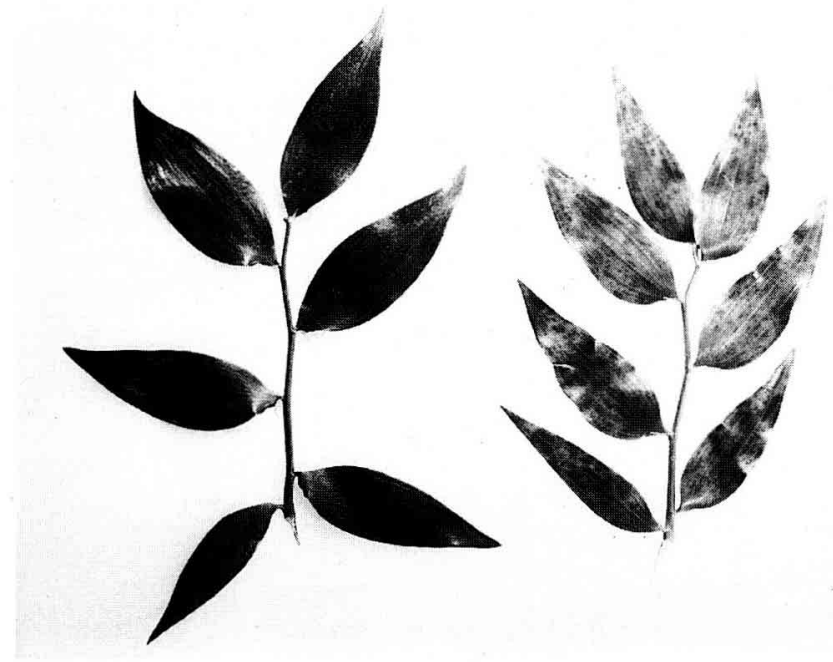

Fig 1. Rameaux de $D$ racemosa ; à droite : cladodes de plant virosé présentant des symptômes de marbrure avec des îlots chlorophylliens entourés d'anneaux plus pâles; à gauche: cladodes de plant sain.

\section{Propriétés physicochimiques du virus}

Un extrait de feuilles de $C$ quinoa développant des symptômes systémiques (isolat $n^{\circ} 1$ ) est préparé dans un tampon phosphate de potassium $25 \mathrm{mM} \mathrm{pH} \mathrm{7,5}$ $(5 \mathrm{ml} / \mathrm{gMF})$. II a été utilisé pour étudier l'inactivation thermique, la limite de dilution et la longévité du pouvoir infectieux avec comme plante test $C$ quinoa ( 3 répétitions par traitement et 4 plantes par répétition).

Le traitement à la chaleur est réalisé sur $1 \mathrm{ml}$ d'inoculum dans un capillaire en verre plongé dans un bainmarie pendant $10 \mathrm{~min}$ à la température désirée. La gamme explorée se situe entre 50 et $90^{\circ} \mathrm{C}$ par palier de $5^{\circ} \mathrm{C}$.

La dilution de l'inoculum a été faite de 10 en 10 dans le tampon de broyage ou dans un extrait du $D$ racemosa sain $(5 \mathrm{ml} / \mathrm{gMF})$. Enfin l'extrait de $C$ quinoa virosé conservé à la température du laboratoire a fait l'objet d'un contrôle d'infectiosité périodique.

\section{Purification du virus}

Le virus est purifié à partir de feuilles de $C$ quinoa inoculées depuis $10 \mathrm{j}$ et présentant des symptômes. Le matériel frais est broyé dans un tampon phosphate de

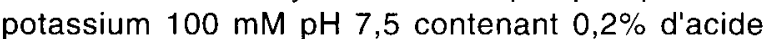
mercaptoacétique ( $3 \mathrm{ml} / \mathrm{gMF}$ ). Après filtration sur étamine, l'extrait est traité par un volume égal de chloroforme froid pendant $10 \mathrm{~min}$. Après centrifugation de 15 min à $5000 \mathrm{~g}$, la phase aqueuse est additionnée de PEG 6000 et de $\mathrm{NaCl}$ (10 et $1 \%$ respectivement) et maintenue à $4^{\circ} \mathrm{C}$ durant $1 \mathrm{~h}$. Une centrifugation de $30 \mathrm{~min}$ à $7500 \mathrm{~g}$ permet de récupérer le virus dans le culot avec un tampon phosphate de potassium $20 \mathrm{mM}$ $\mathrm{pH} 7(0,2 \mathrm{ml} / \mathrm{g} \mathrm{MF})$.

Après clarification, la solution est soumise à une centrifugation de $90 \mathrm{~min}$ à $100000 \mathrm{~g}$. Les culots sont repris dans le même tampon (extrait semi-purifié). Le virus est purifié par ultracentrifugation sur gradient de saccharose $(5-35 \% \mathrm{p} / \mathrm{v})$ durant $3,5 \mathrm{~h}$ à $105000 \mathrm{~g}$ (rotor SW27 Beckman) ; les fractions absorbant à $254 \mathrm{~nm}$ sont récupérées et centrifugées $90 \mathrm{~min}$ à $100000 \mathrm{~g}$. Les culots sont repris dans un tampon phosphate de potassium $10 \mathrm{mM} \mathrm{pH} 7(0,1 \mathrm{ml} / \mathrm{gMF})$

\section{Microscopie électronique}

Différentes suspensions virales semi-purifiées, purifiées traitées ou non par le formaldéhyde à $0,4 \%$ sont examinées au microscope électronique avec comme agent contrastant du molybdate d'ammonium à $0,1 \%$ $(\mathrm{p} / \mathrm{v}) \mathrm{pH} 7$. Une suspension semi-purifiée du virus de la mosaïque du tabac (VMT) est incorporée aux échantillons comme standard de calibration.

\section{Sérologie}

Un lapin a été immunisé par 4 injections intra-dermiques hebdomadaires suivies de 3 rappels mensuels. Chaque injection correspond à $1 \mathrm{mg}$ de virus en émulsion avec de l'adjuvant incomplet de Freund. Après ce laps de temps, des prélèvements de sang sont effectués régulièrement et leur titre est estimé selon la technique de double diffusion en milieu gélosé d'Ouchterlony (Devergne et Cardin, 1967b). Deux tampons sont utilisés : phosphate de potassium $10 \mathrm{mM}$ $\mathrm{pH} 8,6$ ou véronal-véronal sodique $30 \mathrm{mM}$, EDTA $7 \mathrm{mM}, \mathrm{pH} 8,6$.

Les immunoélectrophorèses sont réalisées avec un appareil LKB selon la méthode de Grabar et William (1953) dans le tampon phosphate de potassium $10 \mathrm{mM} \mathrm{pH} \mathrm{8,6.} \mathrm{La} \mathrm{détection} \mathrm{immunoenzymatique}$ (DAS-ELISA) du virus est faite selon le protocole de Clark et Adams (1977) avec des plaques de PVC (Falcon microtest III $n^{\circ} 312$ ). Les échantillons sont préparés par broyage dans un tampon phosphate de potassium $25 \mathrm{mM} \mathrm{pH} \mathrm{7,5-0,5 \%} \mathrm{2-mercaptoéthanol}$ 
(10 ml/gMF) suivi d'une clarification de $15 \mathrm{~min}$ à $5000 \mathrm{~g}$. Les surnageants sont utilisés bruts ou dilués dans du PBS-Tween pH 7,2 contenant $1 \%$ de sérum albumine bovine (IBF fraction $\mathrm{V}$ ) ou des extraits de plantes saines ( $D$ racemosa, $C$ quinoa).

Les propriétés sérologiques du virus isolé de $D$ racemosa (VMD) ont été comparées à celles du virus de la mosaïque du chénopode (VMC), souche isolée de Ficus carica $L$ au laboratoire, avec l'anti-sérum préparé contre le virus de la marbrure du Danae (AVMD) et un sérum anti-virus de la mosaïque de chénopode (AVMC) produit par Vuittenez et Kuszala (1962).

\section{Caractérisation de la protéine capsidiale et de l'acide nucléique}

La taille de la sous-unité capsidiale a été déterminée par électrophorèse sur gel de polyacrylamide selon le protocole de Læmmli (1970). La dissociation de la particule virale est faite par chauffage 4 min à $100^{\circ} \mathrm{C}$ dans le tampon de charge. Le poids moléculaire de la protéine est déterminé en utilisant le kit de calibration LMW de Pharmacia : phosphorylase $\beta$ (94 000), albumine $(67000)$, ovalbumine (43000), anhydrase carbonique $(30000)$, inhibiteur de trypsine $(20100)$ et lactalbumine (14 400). L'acide nucléique viral a été extrait par la méthode phénol-SDS $(1 \%)$ double phase et précipité par 2 fois à l'éthanol en présence d'acétate de sodium 0,3 M. L'acide nucléique $(20 \mu \mathrm{g})$ a été traité par $25 \mu \mathrm{g}$ de RNase pancréatique à $37^{\circ} \mathrm{C}$ durant $2 \mathrm{~h}$. Le pouvoir infectieux a ensuite été contrôlé sur $C$ quinoa. L'essai a été répété 3 fois. La taille de l'ARN a été estimé en utilisant les ARN du virus de la mosaïque du concombre (CMV) par électrophorèse en gel cylindrique $(0,6 \times 10 \mathrm{~cm})$ d'acrylamide à $2,4 \%$ en condition dénaturante (urée $8 \mathrm{M}$ ).

\section{Transmission par aphides}

Les 4 espèces de pucerons étudiées - Aphis fabae Scop, A gossypii Glov, A craccivora Koch, et Myzus persicae Sulz - sont élevés sur Pisum sativum $L$ et proviennent de la station INRA LBI d'Antibes.

Après un jeûne de $60 \mathrm{~min}$, les pucerons sont déposés soit sur des rameaux de $D$ racemosa malade, soit sur $C$ quinoa présentant des symptômes accusés de mosaĩque systémique (isolat Antibes $n^{\circ} 1$ ). Ils y séjournent $10 \mathrm{~min}, 60 \mathrm{~min}$ et $12 \mathrm{~h}$. Les insectes sont ensuite placés sur 3 plantes hôtes : $C$ quinoa, Nicotiana tabacum cv Xanthi nc et Phaseolus vulgaris var «Contender» à raison de 10 individus par plante (2 répétitions).

Après élimination des pucerons par traitement aphicide, les plantes sont cultivées en conditions contrôlées. L'apparition des symptômes est notée et une rétro-inoculation à partir des plantes hôtes est systématiquement effectuée après $10 \mathrm{j}$ sur $C$ quinoa.

\section{Reproduction de la maladie}

Cinq plants de $D$ racemosa et 5 plants de $R$ hypophyllum sains ont été inoculés mécaniquement en présence de carborundum par un extrait de $C$ quinoa virosé (isolat Antibes $n^{\circ} 1$ ). Ces plants ont fait l'objet d'observation pendant plus de 1 an et la présence du virus dans les cladodes inoculés et dans les rameaux néoformés a été vérifiée périodiquement par test biologique sur $C$ quinoa.

\section{RÉSULTATS}

\section{Obtention de symptômes sur $\mathrm{C}$ quinoa et gammes d'hôtes}

Les $C$ quinoa inoculés par des extraits de $D$ racemosa malades n'extériorisent pratiquement jamais de symptômes. Seules, 4 inoculations pratiquées à partir de très jeunes pousses de $D$ racemosa malades ont donné une réponse positive directe. Les feuilles inoculées présentent des taches chlorotiques après 4 à $5 \mathrm{j}$ et une mosaïque systémique avec une légère crispation des feuilles se développe au bout de 8 à 10 j après inoculation (fig 2). Dans la majorité des cas, seule une rétro-inoculation sur $C$ quinoa à partir de feuilles inoculées aboutit à l'expression des symptômes décrits ci-dessus. Les rétro-inoculations à partir de $C$ quinoa non inoculé sont négatives ; de même, l'inoculation avec des extraits de $D$ racemosa sain n'induit aucun symptôme même après 2 rétro-inoculations successives de $C$ quinoa à $C$ quinoa.

Ces résultats ont été obtenus avec les 8 plants de $D$ racemosa sélectionnés présentant des symptômes de marbrure et de jaunissement, ainsi qu'avec une quarantaine d'échantillons collectés en différents endroits. Ils suggèrent que le virus provient effectivement des plants de $D$ racemosa atteint de marbrure et de jaunissement dans lesquels le virus doit se trouver en très faible concentration.

Pour la gamme d'hôtes, les espèces étudiées ont été classées en 4 groupes en fonction de leur comportement après inoculation et rétro-inoculation.

\section{Groupe I}

Espèces ayant extériorisé des symptômes, essentiellement taches chlorotiques locales et mosaïque systémique : Chenopodium amaranti- 


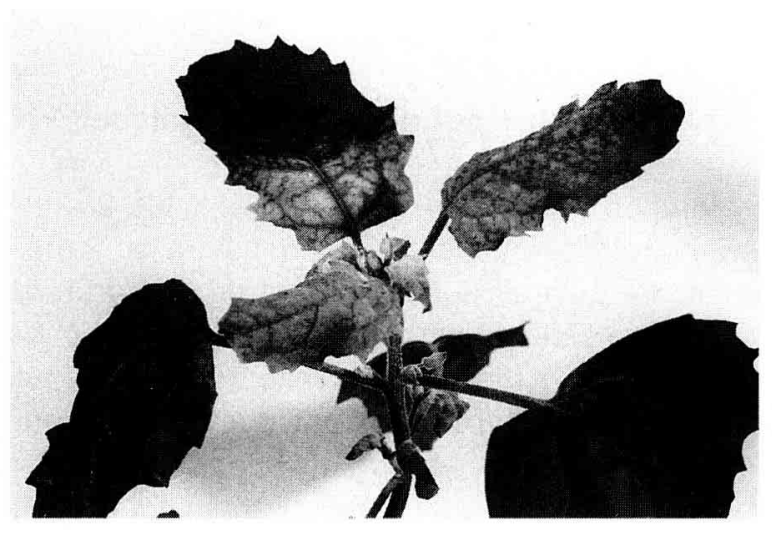

Fig 2. Mosaïque systémique sur Chenopodium quinoa $10 \mathrm{j}$ après inoculation par le virus de la mosaïque du chénopode souche $D$ racemosa.

color Coste et Rayn, Chenopodium murale L, Chenopodium quinoa Wild.

\section{Groupe II}

Espèces dites à «infection latente généralisée», mise en évidence par rétro-inoculation : Balsamina hortensis DC, Claytonia perfoliata Wild, Cucumis melo L var "Védrantais", Cucumis sativus $L$ var "Vert long maraîcher», Dianthus barbatus L, Gomphrena globosa L, Lactuca sativa $L$ var "Reine de mai" et var "Merveilles des 4 saisons", Nicotiana clevelandii Gray et Nicotiana glutinosa L, Petroselinum sativum Hoffn, Phaseolus vulgaris $L$ var "Contender", var "Fin de Bagnol", var "Pinto", var «Victoire", Physalis floridana L, Pisum sativum L var "Diamant", Salvia farinacea Benth, Sphaeralcea munroana Spach, Vallerianella olitoria Poll var "à grosse graine", Vicia fabae $L$ var "Fève d'Aquadulce", Vinca rosea $L$.

\section{Groupe III}

Espèces «dites à infection latente locale», car seules les feuilles inoculées contiennent le virus et il est impossible de mettre en évidence, dans nos conditions, une systémie de l'infection : Beta vulgaris var "Cicla" Moq, Chenopodium bonus henricus L, Cucurbita pepo L, Lycopersicum esculentum $L$ var "Marmande", Lisianthus russellianus Hook, Nicotiana alata Link et Otto, Nicotiana benthamiana Domin, Nicotiana glauca Grah, Nicotiana tabacum L cv Xanthi nc, cv Sansum, var "Virginie D", Nicotiana sylvestris, Spegaz et Come, Ocinum basilicum L, Raphanus sativus $L$, Petunia hybrida Vilm, Salvia splendens $\mathrm{Ker}$, Silene armeria L, Solanum melongena $\mathrm{L}$,
Soya hispida Moench var "King soy", Vicia faba $L$ "féverolle», Vigna sinensis Endl, var «Black», Zinia elegans L.

\section{Groupe IV}

Espèces dans lesquelles le virus n'a pu être réisolé et considérées comme immunes: Capsicum annuum L var "Yolo wonder", Coriandum sativum $\mathrm{L}$, Torenia fournieri $\mathrm{L}$.

II apparaît que le virus possède une large gamme d'hôtes. La majorité des plantes étudiées sont sensibles au virus, mais seules les chénopodiacées développent des symptômes.

\section{Propriétés physicochimiques du virus}

\section{Inactivation thermique}

Selon le protocole défini, le pouvoir infectieux de l'extrait de $C$ quinoa est détruit à $85^{\circ} \mathrm{C}$, température identique à celle publiée par Bennett et Costa (1961).

\section{Limite de dilution de l'inoculum et perte du pouvoir infectieux}

Les plantes inoculées avec la dilution $10^{-7}$ développent toujours une mosaïque systémique. Son apparition est tardive et aléatoire pour des dilutions plus élevées ; les symptômes locaux étant observés pour les dilutions $10^{-9}$ à $10^{-10}$ selon les essais. Ces résultats ne sont pas modifiés par la dilution de l'inoculum dans un extrait de $D$ racemosa sain. Le virus peut être décelé par rétroinoculation bien que les plantes n'extériorisent pas de symptômes dans les feuilles inoculées par les dilutions $10^{-11}$ à $10^{-12}$.

\section{Longévité}

Les extraits de $C$ quinoa virosés conservés à $20^{\circ} \mathrm{C}$ perdent leur pouvoir infectieux après 10 mois.

\section{Purification}

L'analyse en ultraviolet des gradients de saccharose montre la présence de 2 zones : la plus légère ne présente pas de pouvoir infectieux; en revanche, la plus lourde située au milieu du gra- 
dient, est formée de particules virales infectieuses (microscopie électronique et test biologique). Si l'on dispose au sommet du gradient une préparation obtenue par simple précipitation par le PEG sans ultracentrifugation, on observe une bande faible intermédiaire entre les 2 déjà citées formée également de particules virales infectieuses.

Le virus purifié présente un spectre d'absorption classique d'une nucléoprotéine avec un maximum compris entre 260 et $265 \mathrm{~nm}$ et un épaulement net vers $290 \mathrm{~nm}$, ce qui suggère la présence d'acides aminés aromatiques (tryptophane, tyrosine) dans la protéine capsidiale (Baudin, 1976). Le rapport A 260 / A 280 donne sans correction 1,45; Zebzani et al (1986) ont déterminé une valeur de 1,5 pour le virus de la mosaïque du chénopode. Si l'on prend comme référence le coefficient d'extinction du "Sowbane mosaic virus" $\mathrm{CMI} \mathrm{n}^{\circ} 64$ (A $260=4,9$ pour $1 \mathrm{mg} / \mathrm{ml}$ avec $1=1 \mathrm{~cm}$ ), on arrive à des rendements compris entre 300 et $400 \mathrm{mg}$ de virus par $\mathrm{kg}$ de MF de $C$ quinoa.

\section{Microscopie électronique}

L'observation en microscopie électronique des fractions purifiées montre la présence de très nombreuses particules virales de forme isométrique (fig 3). La mesure d'une soixantaine d'entre elles provenant d'une préparation traitée par le formaldéhyde donne un diamètre de $26 \pm$ $1 \mathrm{~nm}$ en prenant comme étalon interne des particules de VMT.

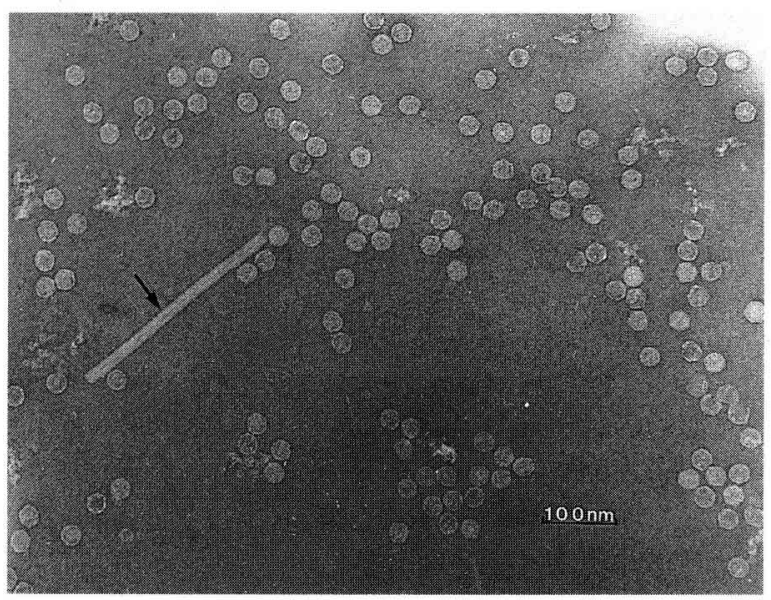

Fig 3. Microscopie électronique : préparation purifiée et formolée du virus de la marbrure du $D$ racemosa (VMD) et particule du virus de la mosaïque du tabac (calibration).

\section{Sérologie}

\section{Immunodiffusion double en milieu gélosé}

En tampon phosphate de potassium, les 2 antisérums réagissent indifféremment avec les 2 préparations de virus purifiés : virus de la marbrure du Danae (VMD) et virus de la mosaïque du chénopode (VMC) (fig 4A). Le raccordement entre les arcs de précipitation est complet, ce qui démontre l'identité sérologique des 2 virus. On observe également un raccordement total avec des extraits des 8 isolats sélectionnés. En milieu véronal, seules les préparations traitées par le formaldéhyde réagissent avec les antisérums (fig 4B). Dans ce tampon, l'absence de précipitation vis-à-vis des préparations non formolées serait liée à la présence de I'EDTA qui favorise l'instabilité et la dégradation des Sobémovirus (Ronald et Tremaine, 1976).

\section{Immunoélectrophorèse}

En fonction des résultats précédents, seul le tampon phosphate de potassium a été utilisé. Les préparations virales non stabilisées par le formaldéhyde migrent moins loin que les préparations formolées (fig 5). Cette différence, due à une plus grande hétérogénéité de l'état des particules dans les préparations non stabilisées par le formaldéhyde, pourrait expliquer les résultats présentés avec cette même technique par Bercks et Querfurth (1969). La migration du VMD formolé révélé par les 2 antisérums AVMD et AVMC
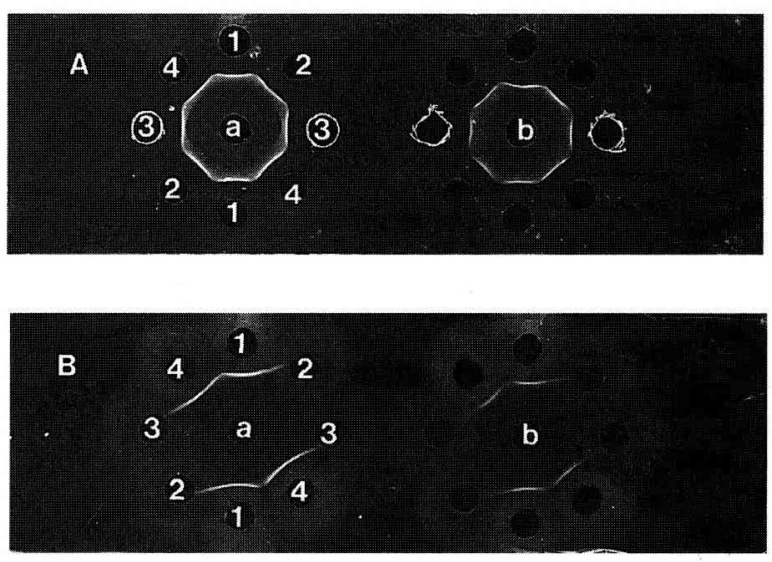

Fig 4. Immunodiffusion double en milieu gélosé. Lame A : tampon phosphate de potassium $10 \mathrm{mM} \mathrm{pH} \mathrm{8,6.} \mathrm{Lame} \mathrm{B} \mathrm{:}$ tampon véronal-véronal sodique $30 \mathrm{mM}$-EDTA $7 \mathrm{mM} \mathrm{pH} \mathrm{8,6.}$ a : antisérum du virus de la marbrure du Danae (AVMD) dilué au $1 / 8 ; \mathbf{b}$ : antisérum du virus de la mosaïque du chénopode (AVMC) dilué au $1 / 8 ; 1$ et 2 : extrait purifié $(1 \mathrm{mg} / \mathrm{ml})$ du virus de la marbrure du Danae (VMD). 1 formolé ; 2 non formolé ; 3 et 4 : extrait purifié $(1 \mathrm{mg} / \mathrm{ml})$ du virus de la mosaïque du chénopode (VMC) : 3 non formolé ; 4 formolé. 

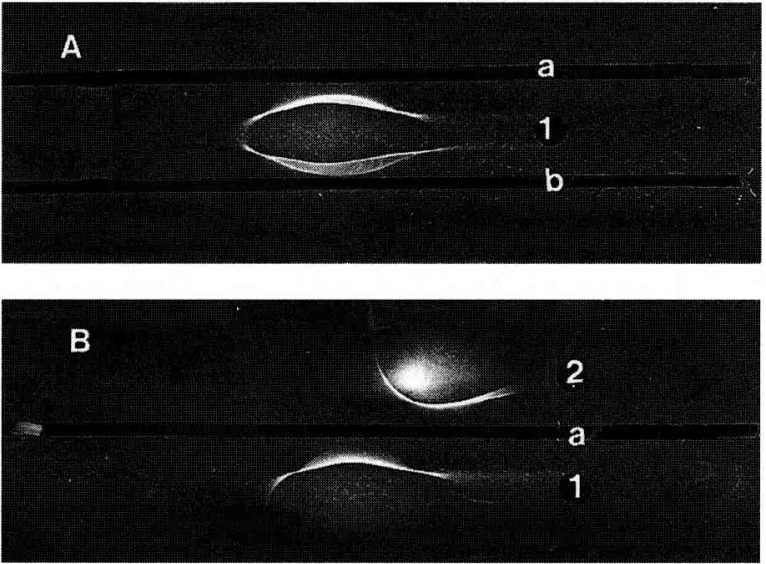

Fig 5. Immunoélectrophorèse en milieu gélosé ; tampon phosphate de potassium $10 \mathrm{mM} \mathrm{pH} \mathrm{8,6.} \mathrm{Lame} \mathrm{A} \mathrm{:} \mathrm{a} \mathrm{:} \mathrm{antisérum} \mathrm{du}$ virus de la marbrure du Danae (AVMD) dilué au $1 / 16$; b : antisérum du virus de la mosaïque du chénopode (AVMC) dilué au $1 / 8.1$ : virus purifié et formolé de la marbrure du Danae (2 $\mathrm{mg} / \mathrm{ml}$ ). Lame B : a : antisérum du virus de la marbrure du Danae (AVMD) dilué au 1/16. 1 : virus purifié et formolé de la marbrure du Danae $(2 \mathrm{mg} / \mathrm{ml}) ; 2$ : virus purifié non formolé de la marbure du Danae $(2 \mathrm{mg} / \mathrm{ml})$.

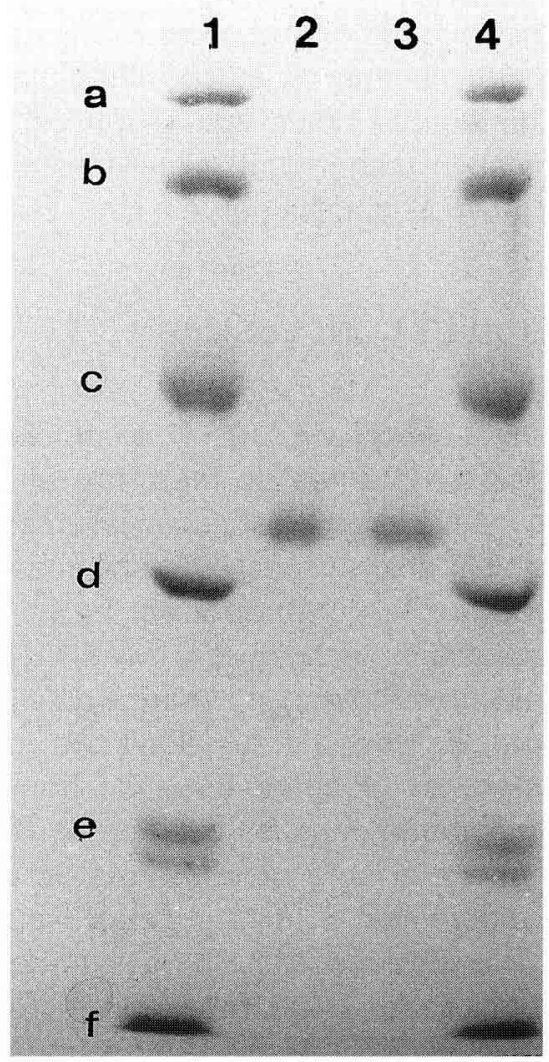

Fig 6. Détermination du poids moléculaire de la protéine capsidiale. Électrophorégramme en gel d'acrylamide $15 \%$; piste 1 et 4 : marqueurs de poids moléculaire ; a) phosphorylase $b$ (94 000) ; b) albumine (67 000); c) ovalbumine (43 000); d) anhydrase carbonique $(30000)$; e) inhibiteur de trypsine (20 100) ; f) lactalbumine (14 400) ; piste 2 : préparation de la sous-unité capsidiale du virus de la marbrure du Danae $(4 \mu \mathrm{g})$; piste 3 : préparation de la sous-unité capsidiale du virus de la mosaique du chénopode souche Ficus carica $(4 \mu \mathrm{g})$. montre des lignes de précipitation qui se raccordent totalement (fig 5) ; le même résultat est obtenu avec le VMC formolé (données non figurées). Dans tous les cas de figure, il n'a jamais été observé de formation d'éperon au niveau des lignes de précipitation, ce qui confirme l'identité sérologique des 2 virus.

\section{Technique DAS-ELISA}

Des courbes de DO établies avec des préparations d'antigènes purifiées des 2 virus (VMD et $\mathrm{VMC}$ ) à des concentrations 1 à $125 \mathrm{ng} / \mathrm{ml}$ sont similaires et superposées. Le seuil de détection est de 1 à $4 \mathrm{ng} / \mathrm{ml}$ respectivement pour les préparations non formolées et formolées, que le virus soit dilué dans le tampon phosphate de potassium ou dans un extrait de $C$ quinoa sain ou de $D$ racemosa sain.

Nous avons vérifié que les isolats du VMD sélectionnés se comportent de manière semblable. À partir des extraits de $C$ quinoa virosés (10 $\mathrm{j}$ après inoculation), la courbe de réponse en fonction des dilutions est identique. La limite de dilution de l'extrait fournissant encore une DO significativement différente (DO 0,06$)$ d'un extrait témoin de $C$ quinoa ou de $D$ racemosa sains (DO $0,012 \pm 0,007)$ se situe dans tous les cas au $1 / 65000$.

Le test pratiqué sur les plants de $D$ racemosa virosé a toujours été négatif, quel que soit le type de tissus choisi (cladodes, jeunes pousses, racines), et ces données confirment la faible concentration du virus dans les plantes de $D$ racemosa virosées.

\section{Estimation du poids moléculaire de la sous-unité capsidiale}

Une seule bande protéique est observée en gel d'acrylamide selon la méthode de Læmmli, dont le poids moléculaire est estimé à $33 \mathrm{kDa}$ (fig 6). Le PM de la sous-unité capsidiale déterminé pour différents isolats de VMC est de $31 \mathrm{kDa}$ (Hill, 1971 ; fiche CMI n 64) ou $32 \mathrm{kDa}$ (Zebzani et al, 1986).

\section{Détermination du type d'acide nucléique et du poids moléculaire de l'ARN}

Les 3 préparations d'acide nucléique du VMD mises à incuber en présence de RNase pancréa- 
tique ont perdu leur pouvoir infectieux, confirmant la nature ribonucléique de l'acide nucléique. Des fractions non traitées à $20 \mu \mathrm{g}, 10 \mu \mathrm{g}, 1 \mu \mathrm{g} / \mathrm{ml}$ ont provoqué le développement des symptômes sur $C$ quinoa et la présence du virus a été vérifié par le test DAS-ELISA.

La préparation d'ARN du VMD et celle du VMC ne présentent qu'un seul pic migrant au même niveau (résultat non figuré). Le poids moléculaire des ARN du CMV déterminés d'après leurs séquences dans le cas de la souche $Q$ du virus sont pour les ARN -1-,2-,3 respectivement de $1,1510^{6}$ (Rezaian et al, 1985), 1,5 $10^{6}$ (Rezaian et al, 1984) et 0,746 106 (Davies et Symons, 1988). En utilisant ces valeurs comme marqueurs la taille de l'ARN du VMD est estimée à $1,310^{6}$, ce qui correspond à celle du VMC (Fiche CMI n ${ }^{\circ} 64$ ).

\section{Transmission par pucerons}

Le tableau I présente les résultats de la transmission du VMD par les aphides étudiés à partir de $D$ racemosa naturellement infecté ou de $C$ quinoa inoculé. Ils montrent que les 4 espèces de pucerons sont des vecteurs potentiels du virus et confirment les résultats antérieurs de Bennett et Costa (1961). II apparaît que la transmission se fait selon le mode non-persistant puisque, dès les 10 premières minutes, les 4 espèces sont capables de contaminer les plantes réceptrices. Phaseolus vulgaris et Nicotiana tabacum, appartenant respectivement aux groupes II et III définis précédemment, ne développent aucun symptôme de la maladie ; seul le test de rétro-inoculation permet donc de juger de la réussite de la transmission. En revanche, $C$ quinoa peut développer des symptômes locaux et systémiques dans de bonnes conditions dès la première inoculation. Après transmisson par puceron, une seule plante a extériorisé des symptômes (plante source : $C$ quinoa; vecteur: $M$ persicae ; séjour $10 \mathrm{~min}$ ). Cette faible efficacité de transmission associée à l'absence de rétro-inoculation explique vraisemblablement pourquoi Dias et Waterworth (1967) ont considéré que $M$ persicae ne pouvait pas transmettre le VMC. Nous avons confirmé que la souche Ficus de VMC prise comme référence était transmise par $M$ persicae sur $C$ quinoa.

Parmi ces 4 espèces, $M$ persicae et $A$ fabae apparaissent les plus efficaces à transmettre le virus, non seulement à partir de $C$ quinoa où le virus est concentré mais également de $D$ racemosa où il l'est très peu. Quelques colonies de cette dernière espèce ont été observées au printemps sur les jeunes pousses en culture.

\section{Reproduction de la maladie}

Après inoculation mécanique du VMD sur $D$ racemosa et $R$ hypophyllum sains, le virus reste présent (test biologique) aux sites inoculés (cladodes) sans toutefois induire de symptômes. On peut détecter le virus pendant 3 mois pour $D$ racemosa et 5 mois chez $R$ hypophyllum. La réponse de $C$ quinoa est très nette pour les premiers contrôles, celle-ci diminue rapidement en intensité et en pourcentage de plants avec symptômes. Au-delà des périodes indiquées le virus n'est plus décelable, même par rétro-inoculation de $C$ quinoa à $C$ quinoa.

Sur les jeunes rameaux en formation, développés 9 mois après l'inoculation, une marbrure avec anneaux verts plus ou moins marqués à été observée sur $D$ racemosa alors qu'aucun symptôme n'est apparu sur les pousses néoformées de $R$ hypophyllum et, pour ce dernier, les tests sur $C$ quinoa ont été négatifs. Les rameaux de $D$ racemosa, au nombre de 6 , ont fait l'objet d'un contrôle biologique positif sur $C$ quinoa après rétro-inoculation démontrant, sans ambiguité, la présence du virus identifié par test DAS-ELISA.

\section{DISCUSSION ET CONCLUSION}

Nous avons isolé un virus de $D$ racemosa présentant des symptômes de marbrure et/ou de jaunissement. Ce virus induit essentiellement des lésions locales chlorotiques puis une mosaïque systémique sur les chénopodes. La mise en œuvre de plusieurs techniques a permis d'identifier ce virus comme étant une souche du virus de la mosaïque du chénopode (Sowbane mosaic virus, groupe des Sobémovirus). Sa fréquence apparaît importante dans les cultures de $D$ racemosa car il a été isolé maintes fois de plants d'origines différentes, dont 2 nouveaux isolats de l'Aude et des Bouches-du-Rhône viennent en confirmation. Enfin, on a reproduit les symptômes de la maladie et réisolé le virus de $D$ racemosa sain préalablement inoculé.

Dans leur étude d'isolats du virus de la mosaïque du chénopode issus de vigne, Bercks et Querfurth (1969) concluaient qu'il fallait s'attendre à trouver ce virus dans d'autres plantes. Effectivement, il a été isolé de plantes d'intérêt agricole ou horticole : cerisier acide (Saric, 


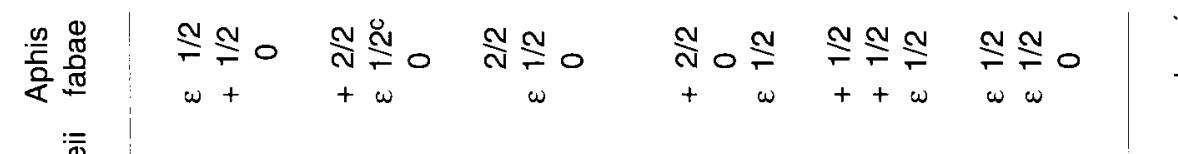

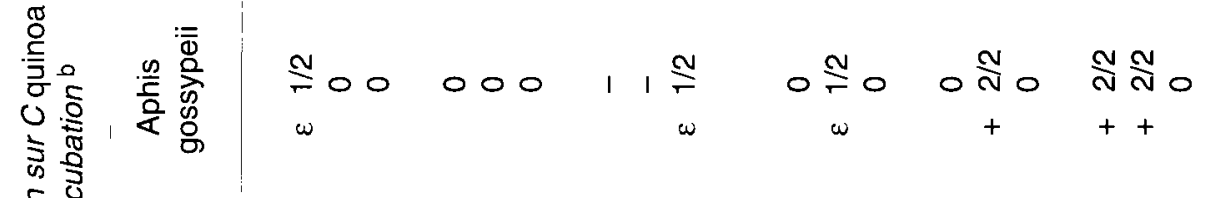

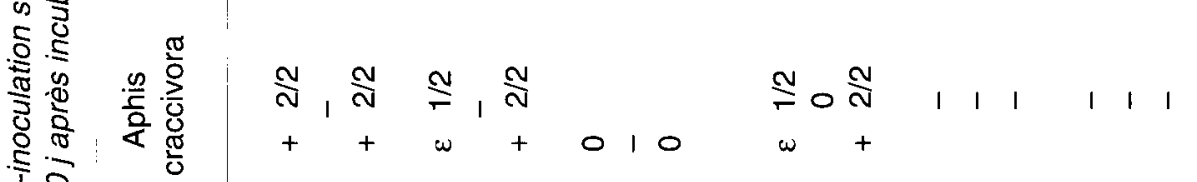
迹足

迹

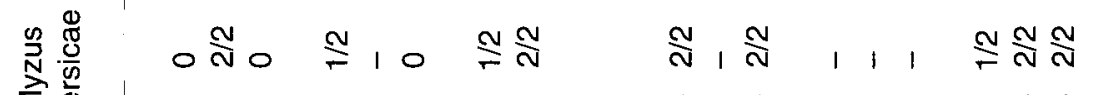

$+\omega \omega+0++\omega+$

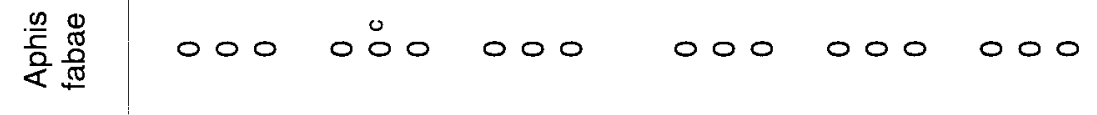

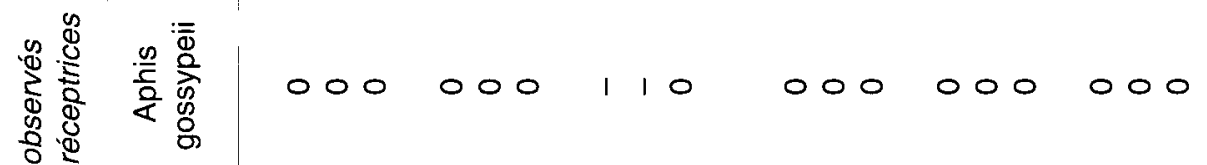

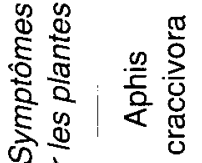

010010010000

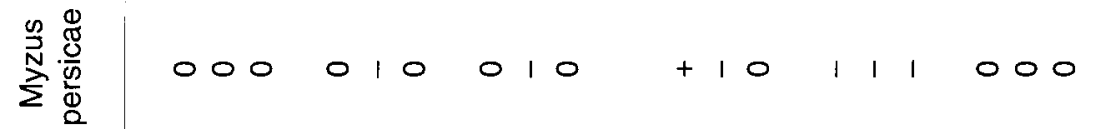

0
0
0
0
0
8
0
0
0

Uza Oza Uza Uza Oza Oza

$\stackrel{8}{\stackrel{8}{\mathbb{2}}}$

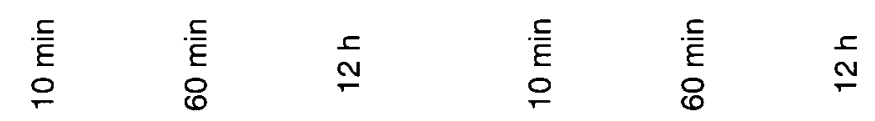

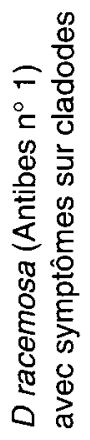

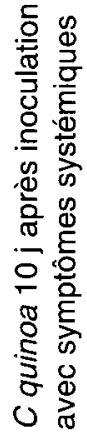


1970), figuier (Quacquarelli, 1971), prunier (Sutic et Juretic, 1976), érable d'ornement (Erdiller, 1986) et betterave à sucre (Buturovic et Juretic, 1980). Mais le Danae racemosa est le premier exemple d'infection naturelle d'une monocotylédone par ce virus.

En fonction de ces résultats, il ne peut s'agir, au départ, d'une contamination accidentelle des semences de chénopodes alors que ce virus est classiquement transmis par la graine (Bennett et Costa, 1961 ; Vuittenez et Kuszala, 1962 ; Dias et Waterworth, 1966 ; Kado, 1966). L'utilisation de ces plantes pour la détection et la purification de virus végétaux a été particulièrement bien étudiée par Vuittenez et Kuszala (1962) et Engelbrecht et Van Regenmortel (1968). Ce risque étant bien connu, toutes les précautions sont prises depuis de nombreuses années pour la production de semences de chénopodiacée.

La transmission du virus de la mosaïque du chénopode par diptère (Liriomyza langei Frick), homoptère (Circulifer tenellus Baker), hémiptère (Halticus citri Ashmead), aphide (Myzus persicae Sulz) a été établi par Bennett et Costa (1961). Récemment, celle-ci a été démontrée par Thrips tabaci Lind ainsi qu'avec le pollen de chénopode infecté par Hardy et Teakle (1992). Dias et Waterworth (1986) ne pouvaient confirmer la transmission par $M$ persicae. Dans cette étude, hormis un cas de transmission directe, c'est la rétro-inoculation systématique sur $C$ quinoa qui a permis de démontrer que le virus (souche Danae) était transmis par 4 espèces de pucerons dont $M$ persicae (souche Danae et souche Ficus). Si les pucerons peuvent disséminer le virus, il pourrait exister une autre possibilité avec Otiorrynchus sulcatus F. En effet, ce curculionide provoque très fréquemment des dégats importants sur $D$ racemosa : cladodes découpés à «l'emporte-pièce» sur leur périphérie (Del Bene, 1984). Ce charençon connu comme nuisible à la vigne (Hofmann in Balachowsky, 1963), où le VMC a été signalé (Bercks et Querfurth, 1969 ; Pozdena et al, 1977), pourrait être un vecteur potentiel de ce virus. Cette hypothèse est renforcée par le fait que les autres virus du groupe des Sobémovirus sont transmis par coléoptères (Sehgal, 1981) et que, d'après leur observation, Costa et al (1958) suggéraient déjà une transmission de type mécanique pour ce virus.

La très faible concentration du virus dans le $D$ racemosa, puisque toutes les épreuves immunoenzymatiques (DAS-ELISA) effectuées à partir de cette plante se sont révélées négatives, et le phénomène de latence observé chez les chénopodes pour la première inoculation sont les caractéristiques principales résultant de cette étude. La conséquence immédiate est de poser le problème du diagnostic, d'autant plus que les symptômes peuvent être atténués, voire inexistants, selon les conditions culturales (ombrage, fertilisation azotée).

Dans un schéma de sélection sanitaire, il apparaît nécessaire de maintenir impérativement l'indexage biologique avec rétro-inoculation sur $C$ quinoa suivi, éventuellement, d'un contrôle immunoenzymatique de confirmation. Dans la perspective d'une production de plants sains (travail en cours), le développement de moyens de détection plus performants en utilisant des techniques moléculaires comme l'amplification de I'ARN viral et l'usage de sondes nucléiques spécifiques seraient particulièrement utiles pour le contrôle sanitaire de plants de $D$ racemosa après multiplication végétative in vitro et (ou) régénération à partir d'apex méristématiques.

\section{RÉFÉRENCES}

Baudin P (1976) Étude d'une souche du virus de la mosaïque de la canne à sucre. Thèse doct ingén, univ Louis-Pasteur, Strasbourg 1, $59 \mathrm{p}$

Bennett CW, Costa AS (1961) Sowbane Mosaic caused by a seed-transmitted virus. Phytopathology 51 , 546-550

Berck R, Querfurth G (1969) Uber den Nachweis des Sowbane mosaic virus in Reben. Phytopath Z 66, 365-373

Buturovic D, Juretic N (1980) Finding of Sowbane Mosaic in sugar beet. Acta Bot Croatia 39, 9-13

Clark MF, Adams AN (1977) Characteristics of the microplate method of enzyme-linked-immunosorbent-assay for the detection of plant viruses. J Gen Virol 34, 475-483

Costa AS, De Silva DM, Duffus DE (1958) Plant virus transmission by a leaf-miner fly. Virology 5,145 149

Davies C, Symons RH (1988) Further implication for the evolutionary relationships between tripartite plant viruses based on cucumber mosaic virus RN3. Virology 165, 216-224

Del Bene G (1984) Prove di lota control Otiorrhynchus sulcatus F sur Ruscus Danae racemosa in Toscana. Riv Ortoflorofrutt it 68, 299-306

Devergne JC, Cardin L (1967) Utilisation de la réaction sérologique en immunodiffusion comme test de diagnostic du virus du Mottle de l'œillet. Ann Epiphyt 18 , HS, 85-103

Dias MF, Waterworth HE (1967) The identity of a seed-borne mosaic virus of Chenopodium amaranticolor and C quinoa. Can J Bot 45, 1285-1295 
Engelbrecht DJ, Van Regenmortel MHV (1968) The problem of Sowbane mosaic virus contamination. Phytopath Z63, 10-14

Erdiller G (1986) Acer virus diseases in Turkey. J Turk Phytopathol 15, 46-49

Grabar P, Williams CA (1953) Méthode permettant l'étude conjuguée de propriétés électrophorétiques et immunologiques d'un mélange de protéines. Application au sérum sanguin. Biochim Biophys Acta 10, 193-194

Hardy UG, Teakle DS (1992) Transmission of Sowbane mosaic virus by Thrips tabaci in the presence and absence of virus-carrying pollen. Ann App/ Biol 121, 315-322

Hofmann A (1963) Otiorrynchinae. In : Entomologie appliquée à l'agriculture (Balachowsky, ed), Masson, Paris, 878-912

Kado $\mathrm{Cl}$ (1966) Purification and characterization of a semilatent seed-borne virus in Chenopodium amaranticolor. Phytopathology 56, 844 (abstr)

Kado $\mathrm{Cl}$ (1971) Descriptions of Plant Viruses. $\mathrm{N}^{\circ}$ 64: Sowbane mosaic virus CMI/AAB

Laemmli UK (1970) Cleavage of structure proteins during assembly of the head bacteriophage T4. Nature 227, 680-685

Pozdena J, Vanek G, Filligarova M (1977) Sowbane mosaic virus on grapevine in Czechoslovakia. Ockrana Rostlin 13, 197-200

Quacquarelli A (1971) Fig mosaic and a virus latent in chenopodium. Phytopath Mediterr 10, 283-286

Rezaian MA, Williams RHV, Gordon KHJ, Gould AR, Symons RH (1984) Nucleotide sequence of cucum- ber mosaic virus RNA-2 reveals a translation product significantly homologous to corresponding proteins of other viruses. Eur J Biochem 143, 277 284

Rezaian MA, Williams RHV, Symons RH (1985) Nucleotide sequence of cucumber mosaic virus RNA-1. Presence of a sequence complementary to part of the viral satellite RNA and homologies with other viral RNAS. Eur J Biochem 150, 331-339

Ronald WP, Tremaine JH (1976) Comparison of the effects of sodium dodecyl sulfate on some isometric viruses. Phytopathology 66, 1302-1309

Saric A (1970) La présence de Sowbane mosaic virus chez le cerisier acide. VIII. Symposium européen sur les maladies à virus des arbres fruitiers, Bordeaux 24-30 juin 1970. Ann Phytopathol $n^{\circ} \mathrm{HS}$, 155-158

Sehgal OP (1981) Southern bean mosaic virus group. In : Handbook of Plant Virus Infections and Comparative Diagnosis (E Kurstak, ed), Elsevier/North Holland Press, 91-121

Sutic OP, Juretic N (1976) Occurring of Sowbane mosaic virus in plum tree. Acta Hortic 66, 328 (Abstr)

Teakle DS (1968) Sowbane mosaic virus infecting chenopodium trigonon in Quensland. Austral J Biol Sci $221,649-653$

Vuittenez A, Kuszala J (1962) Propriétés d'un virus agent d'une mosaïque des chénopodes. Études Virol Appl 3, 15-22

Zebzani M, Lochart BEL, Hill JH (1987) Identification of 3 serotypes of sowbane mosaic virus. Phytopathology 77, 571-574 